\title{
A Revealed Preference Approach for Ranking City Quality of Life
}

\author{
by \\ Matthew E. Kahn, Columbia University
}

October 1993

Discussion Paper Series No. 669

$d p-929-66$ 


\section{A REVEALED PREFERENCE APPROACH FOR RANKING CITY QUALITY OF LIFE}

By Matthew E. Kahn, Columbia University

Discussion Paper No. 669

October 1993

This paper is a revised version of Essay Three of my August 1993 University of Chicago Dissertation; "Three Essays of Environmental Economics". I thank my committee; Sherwin Rosen, Gary Becker and Robert Willis for many helpful comments. Conversations with Derek Neal greatly improved this paper. I also thank Dora Costa and Anna Paulson for helpful comments. All errors are mine. 


\begin{abstract}
This paper presents a new method for ranking city quality of life that requires weaker assumptions than the Rosen and Roback hedonic methodology. A simple revealed preference approach is used. If a person can raise his wages and lower his rentals by moving from city $a$ to city $b$, then city a must be nicer than city $b$.

This approach differs from the hedonic approach because a separate fixed effect is estimated for each city. The fixed effect represents the dollar value of the entire bundle of a city's local public good vector. The revealed preference approach relaxes the assumptions that: 1) All relevant city specific attributes are observed, and 2) the functional form of how attributes affect wages and rentals is known. I also show how this estimator can be used to study city quality of life dynamics from a single cross-section of rentals and home prices across cities.
\end{abstract}




\section{Introduction}

Different cities offer different bundles of non-market local public goods. Some locations may have a mild climate or an excellent public school system. If a city is defined as a point in some $\mathrm{k}$ dimensional attribute space, then an index problem exists. How can we collapse these $\mathrm{k}$ dimensions into an index to rank city quality of life? Early quality of life studies ranked cities using adhoc weights (Liu 1976).

Rosen (1979) and Roback (1982) presented an alternative methodology for estimating city quality of life. They estimated the local public goods index weights by studying intercity wage differentials. If migration costs are zero, then a given worker's wage in a given city should reflect both his productivity and the capitalization of that city's local public goods. The theory of compensating differentials predicts that, controlling for productivity, wages will be lower in high attribute cities. ${ }^{1}$ Many authors have used this framework to justify estimating hedonic wage and rental regressions to recover the implicit attribute index weights. ${ }^{2}$

The typical hedonic wage regression estimation strategy begins with a large crosssectional data set, such as the Census of Population and Housing. For each individual in the

${ }^{1}$ Roback (1982) shows that if non-market attributes have no effect on firm productivity or if firms do not need land as an input to production, high attribute cities will also have high rents.

${ }^{2}$ See Rosen (1979), Roback (1982) and Blomquist et. al. (1988). Gyourko and Tracy (1991) extend this approach by showing the importance of accounting for spatial variation in local taxes. Unlike some local public goods that are supplied exogenously, such as climate, some local public goods are supplied by the local government and will be paid for through higher local taxes. 
data set, the researcher knows that individual's wage, location, education, experience, ethnicity, and occupation. A second data set containing information on each city's characteristics is then merged, by city, to the individual data. An augmented "Mincer" wage regression is estimated such that the regression includes all observed local city specific characteristics. The estimated coefficients on the city specific variables, such as air pollution, are interpreted as the implicit price of that local public good. Implicit in this estimation strategy are the assumptions that all relevant city specific local public goods are observed and that individuals are not sorting on unobservables across cities. ${ }^{3}$

This paper presents an alternative method for ranking city quality of life that relaxes the assumption that all relevant city characteristics are observed. A simple revealed preference approach is used. If a person can raise his wages and lower his rentals by moving from city a to city $b$, then city a must be nicer than city $b$. This approach differs from the hedonic approach because a separate fixed effect, the constant, is estimated for each city. This constant reflects the dollar value of the entire bundle of a city's local public good vector. The revealed preference approach relaxes the assumptions that: 1) All relevant city specific attributes are observed, and 2) the functional form of how attributes affect wages and rentals is known.

Unlike previous quality of life studies, I estimate separate factor prices, such as the returns to education, for each city. Rosen (1983) and Heckman and Scheinkman (1987)

\footnotetext{
${ }^{3}$ Urban economists use linear regression to impute the counterfactual of what I would earn had I located in a city I did not choose. If people are self selecting across cities, then the urban economist cannot construct the counterfactual of what the average college graduate in Chicago would have earned had he lived in Boston from observing the college graduates in Boston because the two groups are not comparable.
} 
present skill bundling models that show why a "law of one price" does not have to hold across space. Spatial variation in wages may represent spatial variation in productivity not locational amenities. Since a person is only observed in one city, each person's wage and rental is imputed in every other city. These predictions are generated by evaluating each person's characteristics at each city's estimated price vector. If high ability people select into high attribute cities then an econometrician cannot construct the counter-factual of what such people would have earned had they chose to live in another city. ${ }^{4}$ Similar to Rosen (1979) and Roback (1982), I must assume that people are not sorting on unobservables across cities. People must be just indifferent between living in any of the cities in my sample. Only when people are indifferent across cities, will each city contain a representative sample of the nation's population. ${ }^{5}$

All quality of life research has focused on a cross-sectional ranking of which cities are the nicest. This paper shows how the revealed preference methodology can be used to determine which cities are expected to rise in the relative city quality of life ranking in the future. I show how a single cross-section on home prices and rentals across cities reveals city quality of life dynamics.

${ }^{4}$ This spatial Roy model would lead the econometrician to underestimate the implicit prices of attributes because people consuming a high attribute bundle would earn high wages. In an extreme case, the econometrician might mistake amenities for disamenities because the "identical" person would receive compensation for living in the nice city.

${ }^{5}$ If one type of people were earning quasi-rents in Detroit, i.e. they were not indifferent between Detroit and Boston, then none of this type would live in Boston thus Boston could not contain a representative sample of the nation's population. Without a representative sample of the nation, it is impossible to use least squares to impute the counterfactual of what the average person outside that city would have earned had he located in your city. 
Using 1980 census data for 6 major SMSAs, I find that Los Angeles is the highest quality of life city and that Chicago and Houston are the lowest.

This paper is organized as follows: Section Two presents the estimator and contrasts it to the hedonic estimator. Section Three shows how this approach can be used to estimate city quality of life dynamics. Section Four presents an example using 1980 Census data. Section Five concludes.

\section{The Revealed Preference Approach}

Suppose that all agents in an economy have identical preferences defined over consumption, $\mathrm{C}$, and a $\mathrm{k}$ dimensional vector of attributes, $\mathrm{A}$. In addition, suppose that an agent's consumption of $\mathrm{C}$ and $\mathrm{A}$ is solely a function of locational choice. If migration costs are zero and all agents have equal ability then an equilibrium will consist of a rental and a wage gradient and an allocation of agents across cities such that no person can raise his utility by moving. If all agents are identical and indifferent between living in different cities and if we observe that people in San Francisco have lower consumption than people in Chicago, we can immediately infer that San Francisco offers a higher A bundle than Chicago. If the two cities had equal A bundles then everyone in San Francisco could raise their utility by moving to Chicago. Note that this argument provides no insights into what parts of the k dimensional vector determine the "niceness" of San Francisco. The empirical part of this paper estimates how much consumption a person is sacrificing by remaining in one's current city of residence. 
To rank city quality of life, each person's wage and rental in every city must be estimated. The methodology proceeds in two steps. In step one, a wage and rental regression is estimated for all agents in every city. This recovers each city's "price vector". In step two, these estimates are used to predict all agents' wages and rentals in every city. Step One: Estimate for each city $\mathrm{j}$ :

$$
\begin{aligned}
& \text { Wage }_{i j}=X_{i} \beta_{j}+U_{i j} \\
& \text { Rent }_{i j}=Q_{i} \gamma_{j}+V_{i j}
\end{aligned}
$$

Step Two: Predict each person's wage and rental in every other city:

$$
\begin{aligned}
& \operatorname{Wage}_{i j}=X_{i} \beta_{j}^{*} \\
& \operatorname{Rent}_{i j}=Q_{i} \gamma_{j}^{*}
\end{aligned}
$$

$$
\begin{gathered}
\text { Wage }_{i j}=\text { person } \mathrm{i} \text { in city j's wage } \\
\text { Wâge }_{\mathrm{ij}}=\text { person i predicted city } \mathrm{j} \text { wage } \\
\text { Rent }_{\mathrm{ij}}=\text { person } \mathrm{i} \text { in city j's rent } \\
\text { Rênt }_{\mathrm{ij}}=\text { person i predicted city } \mathrm{j} \text { rent } \\
\mathrm{X}_{\mathrm{i}}=\text { person i's characteristics } \\
\beta_{\mathrm{j}}{ }^{*}=\text { estimate of city } \mathrm{j} \text { 's wage coefficient vector } \\
\gamma_{\mathrm{j}}^{*}=\text { estimate of city } \mathrm{j} \text { 's rental coefficient vector }
\end{gathered}
$$




$$
\begin{aligned}
& Q_{j}=\text { person } i \text { 's housing characteristics } \\
& U_{i j}=\text { disturbance term, iid mean zero } \\
& V_{i j}=\text { disturbance term, iid mean zero }
\end{aligned}
$$

Implementing Step Two yields predictions of each individual's wage and rental in every city. Note that the constant in equations (1-2) and factor prices are allowed to vary across cities.

These predictions can be used to construct two types of quality of life indices. The first method is a counting index. If the sample includes $b$ cities, then equations (1) and (2) yield a b x b matrix with element $(c, j)$ equal to:

$$
k_{j}^{-1} \sum_{i=1}^{k_{j}} 1\left(\left(\text { Wage }_{i c}-\text { Wage }_{i j}>0\right) * 1\left(\left(\text { Rent }_{i c}-\text { Rênt }_{i j}\right)<0\right)\right.
$$

Where 10 is an indicator function that equals one if the statement in parentheses is true, zero otherwise. Intuitively, the product of the indicator functions equals one if a person can raise his predicted wages and lower his predicted rentals by moving from city $\mathrm{j}$ to city $\mathrm{c}$. If either of these conditions does not hold, the product of the indicator functions will equal zero. ${ }^{6}$

Equation (5) represents the percentage of people in city $\mathrm{j}$ who by moving to city $\mathrm{c}$ can have higher predicted wages and lower predicted rentals. By taking a weighted average across cities, "entry" and "exit" quality of life rankings are constructed. The "entry" ranking predicts what percentage of people can raise their wages and lower their rentals by moving to a given

\footnotetext{
${ }^{6}$ Note that in equation (5), a person's actual wage and rental information could certainly be used.
} 
city. The "exit" ranking predicts what percentage of people can raise their wages and lower their rentals by moving away from that city.

A second quality of life index calculates the gain in "surplus" from moving. A low attribute city may offer the same wages but much lower rentals than a nice city. In this case, the counting index would suggest that the two cities are of equal quality. A simple method for addressing this case is to introduce the monthly surplus function. This function is measured in dollars and represents the monthly gain for person $i$ of moving from city $j$ to city $q{ }^{7}$ It is defined as:

$$
\operatorname{surplus}(i, q, j)=\text { Wage }_{i q}-\text { Wage }_{i j}-\operatorname{Rent}_{i q}+\operatorname{Rent}_{i j}
$$

To estimate $\operatorname{surplus}(i, q, j)$, predicted values are substituted for each term in equation (6). Unlike the "counting" method, this method has a cardinal interpretation. Since surplus is measured in dollars, this approach allows one to study not only the ranking but the "distance" between cities.

This approach differs from Rosen's (1979) and Roback's (1982) framework because no attempt is made to estimate which locational attributes are the key to determining city quality of life. Their approach estimates separate national hedonic wage and rental regressions.

\footnotetext{
${ }^{7}$ I assume that the amount of labor supplied is invariant to what city a person lives in.
} 


$$
\begin{gathered}
\text { Wage }_{i j}=X_{i} \beta+Z_{j} \Gamma+\varepsilon_{i j} \\
\text { Rent }_{i j}=Q_{i} \gamma+Z_{j} \xi+\mu_{i j} \\
\text { Wage }_{i j}=\text { person i in city j's wage } \\
\text { Rent }_{\mathrm{ij}}=\text { person i in city j's rent } \\
X_{\mathrm{i}}=\text { person i's characteristics } \\
\mathrm{Q}_{\mathrm{i}}=\text { person i's housing characteristics } \\
Z_{\mathrm{j}}=\text { city j's characteristics } \\
\mu_{\mathrm{ij}}=\text { rental disturbance term } \\
\varepsilon_{\mathrm{ij}}=\text { wage disturbance term }
\end{gathered}
$$

Standard assumptions are that $\mathrm{E}\left(\varepsilon_{\mathrm{ij}} \mid X_{\mathrm{i}}, \mathrm{Z}_{\mathrm{j}}\right)=0$ and $\mathrm{E}\left(\mu_{\mathrm{ij}} \mid \mathrm{Q}_{\mathrm{i}}, \mathrm{Z}_{\mathrm{j}}\right)=0$ and that skill prices (the $\beta$ 's) and attribute prices ( $\Gamma$ and $\xi$ ) are the same in each city. These assumptions impose that there are no unobserved city or person specific attributes that are correlated with observables. In addition these assumptions imply that spatial variation in wages and rentals is not due to spatial differences in factor prices. A "law of one price" is imposed. Since workers and apartments are bundled commodities, it is possible that each of the components of the bundle do not sell at the same price. Estimates of the $\Gamma$ and $\xi$ vectors are used as weights to construct a city quality of life ranking. If a given attribute such as air quality has little impact on rents or wages then we infer that this attribute is not an important component 
of a quality of life index. ${ }^{8}$

A comparison of equations (1-2) and equations (7-8) reveal several differences between the hedonic and revealed preference approach. My approach relaxes the assumption that all location specific attributes are observed and that they enter linearly into the regression. Instead, city specific attributes are priced into the city specific constant. Since all attributes are priced into the constant, this method avoids any attribute multicollinearity problems that have affected inference from hedonic regression (see Rosen 1979). ${ }^{9}$ I estimate separate skill prices by city. Hedonic studies have fully interacted the wage or rental specification to allow factor prices to vary spatially.

Note that the city specific disturbance terms in equations (1-2) are assumed to be independently and identically distributed. In recent hedonic quality of life studies, Gyourko and Tracy (1991) have followed Moulton's (1990) suggestion of assuming that the disturbance terms in equations (7) and (8), $\mu$ and $\varepsilon$, each have a covariance structure that is block diagonal. Within each city, individual's wage disturbance terms are equi-correlated, because they cohtain common local public goods that are not observed. Across cities the disturbance terms are independent. My approach re-writes the random effect as a fixed effect. Gyourko and Tracy (1991) use a Lagrange multiplier test to estimate whether the

${ }^{8}$ Blomquist et. al. (1988) present the comparative static results for combining the wage and rental regression coefficients into a "total attribute" price that is used to construct their quality of life index.

9 For example, many measures of air pollution and rainfall are strongly negatively correlated. It is possible that a hedonic regression may yield results which suggest that when both attributes are included in the regression neither one is significant. The researcher might then infer that rainfall and air pollution are not important components of a quality of life index. 
observables are correlated with observables. They could not reject the hypothesis that the disturbance term was uncorrelated. Since the revealed preference estimator treats the random effect as a fixed effect, it is a more powerful estimator of quality of life rankings.

\section{City Quality of Life Dynamics}

This section uses the revealed preference approach to study city quality of life dynamics. Using a single cross-section of rentals and home prices, I show how to predict those cities whose quality of life is expected to improve. Controlling for its physical characteristics, a rental reflects only the value of the vector of today's attributes of the city it is located in. A home is a durable. Controlling for its physical characteristics, a home price reflects the expected discounted dividend stream of the characteristics of the city. Suppose that all rentals and homes have identical physical characteristics except that a renter is only paying for the right to live in that city for one year while the home owner is buying the right to live there forever. Under these assumptions, if a city's local public goods vector is constant then the discounted infinite sum of today's rental will equal today's home price. If a city's local public goods vector is expected to improve in the future then the discounted sum of today's rental will be less than today's home price.

Why might a city's local public goods vector change over time? The typical hedonic analysis, see Blomquist et. al.(1988), includes climatic variables such as sunshine, temperature, and coastal access that do not change in any systematic pattern over time. Other variables such as air quality, the presence of Superfund toxic waste sites, quality of 
public schools, educational attainment of city residents, crime, the AIDS epidemic, can change over time. Except for Abelson and Markyandya (1985), most researchers have implicitly assumed that the bundle of local public goods is constant or that people have static expectations.

I present a simple test to predict which cities are expected to enjoy a quality of life improvement. Unlike previous researchers, I do not pool rental and home price data (see Blomquist et. al. 1988 and Gyourko and Tracy 1991). ${ }^{10}$ Researchers who pool rentals and home prices are throwing away interesting information about expectations about future local public goods.

A city specific log rental and log home price regression is estimated for each city:

$$
\log \left(\text { rent }_{i j}\right)=\alpha_{j}+Q_{i} \gamma_{j}+V_{i j}
$$

To link the cross-sectional rental gradient to cross-sectional variation in home prices, suppose that 1) location specific attributes never change, and 2) the prices of location specific attributes are constant. Under these assumptions if the set of rentals is representative of the housing stock then home prices will equal the present value of the rentals.

$$
\begin{gathered}
\log \left(\text { home }_{i j}\right)=\log \left(\text { rent }_{i j} / r_{j}\right) \\
\log \left(\text { home }_{i j}\right)=\alpha_{j}-\log \left(r_{j}\right)+Q_{i} \gamma_{j}+V_{i j}
\end{gathered}
$$

${ }^{10}$ These papers convert home prices into rentals by multiplying the home price by an interest rate that in Blomquist et. al. (1988) is $7.5 \%$. 


$$
\log \left(h_{h} e_{i j}\right)=\theta_{j}+Q_{i} \gamma_{j}+V_{i}
$$

Equation (10) links the hedonic rental and home price regressions. A restriction can be imposed for each city, relating the rental intercept, alpha, to the home price intercept, theta.

Assuming that interest rates, $r_{j}$, are equal across cities after estimating a rental and home price regression for each city, I can test the following set of restrictions:

$$
\log \left(r_{j}\right)=\alpha_{j}-\theta_{j}=\alpha_{q}-\theta_{q}=\log \left(r_{q}\right)
$$

The interest rate estimates from equation (13) can be used to rank cities in terms of expected future amenities. Suppose that for Chicago, the difference between the rental intercept and the home intercept is relatively small. From equation (13), this indicates that the estimated interest rate is relatively low. If the implicit price of non-market city attributes are constant over time, a large Chicago home intercept can only be generated by an expected future increase in a Chicago specific attribute. For example, if a Superfund site in Chicago will be clean in two years, this will affect the home intercept but not the rental."

To summarize, the methodology for ranking city quality of life dynamics is to first estimate a rental and house price regression for each city. Next perform one-sided F-Tests for all cities based on equation (13). The cities with the lowest estimated interest rates are those whose quality of life is expected to increase the most. If all interest rates were equal,

\footnotetext{
${ }^{11}$ Phillips (1988) finds cross-sectional variation in the 1980 residential capitalization rate, $r$ in equation (10). My interpretation of his results are that Atlanta, Detroit, Philadelphia and St. Louis all had declining quality of life and that Washington DC, San Francisco, and Los Angeles had rising quality of life in 1980.
} 
then we would conclude that quality of life across cities does not change over time.

This procedure will only yield a valid estimate of city quality of life dynamics if rentals and homes are equally distributed across space in each city. For example, if in Chicago all the rentals are in the worst part of town then my rental regression for Chicago will indicate a low rental intercept relative to home prices. 


\section{Empirical Results}

The 1980 Census of Population and Housing Public Use Sample A is used to rank city quality of life. My sample consists of male heads of households, aged 25-60, who live in one of six major SMSAs (New York, Houston, San Francisco, San Diego, Chicago, or Los Angeles) who earned at least three dollars an hour and who worked over 780 hours in 1979. All of the men in the sample are United States citizens and none are disabled. I use only renters because they face lower migration costs than home owners. A disadvantage of the revealed preference approach is that it requires regression within a given geographical unit. This requires a large number of observations within each city. There are only 224 observations for Chicago, 127 for Houston, 282 for Los Angeles, 454 for New York and 73 for San Diego and 150 observations for San Francisco. ${ }^{12}$

An advantage of working with major cities is that this partially controls for differential price levels across locations. With the exception of Gyourko and Tracy (1991), most researchers have not deflated the prices in cross-sectional regressions. The Bureau of Labor Statistics has constructed price indices for only about 30 SMSAs. Blomquist et. al. (1988) had over 180 SMSAs in their sample. If the price of non-durables, like food, differs across space, nominal price variation may not represent compensation for location specific goods. I present deflated results using the 1982 food CPI index. The base year is 1967 . The index was 271.8 for Chicago, 305 for Houston, 271.8 for Los Angeles, 280.6 for New

\footnotetext{
${ }^{12}$ The summary statistics are reported in Table 1.
} 
York, 279.3 for San Diego and 277.1 for San Francisco. I have also estimated quality of life rankings using the nominal data and have found roughly the same results. Working with only major cities may also control for selection issues. Implicitly, I am assuming that Chicago's population is representative of Los Angeles' population. Researchers using the hedonic method have combined New York City and small towns in Kansas when estimating equations (7-8). It is not believable that the people in a small town in Kansas are representative of the people in New York City.

Table 2 presents log wage regressions for each city. For the wage regression, the independent variables include; years of school, experience, and experience squared. The regressions suggest substantial skill price variation. An extra year of schooling in New York, increases wages by $5.6 \%$ while in San Francisco an extra year of schooling increases wages by only $1.6 \%$. In these city specific regressions, the constant reflects the value of all location specific goods. I find significant variation in the constant across cities with San Francisco having the highest constant and New York having the lowest. Note the relatively low $\mathbf{R}$ squared in each regression.

Table 3 presents level rent regressions for each city. For the rent regression, the independent variables include; the apartment's age, and number of rooms. Controlling for these factors, the constant represents the price of all non-market goods offered by the city. The results are quite intuitive. Newer, larger apartments have a higher rent. It is interesting to note that the three California cities, Los Angeles, San Diego, and San Francisco, all have quite similar constants.

Table 4 presents the city quality of life transition matrix defined in equation (5). This 
table indicates that $82 \%$ of the people in Los Angeles can raise their wages and lower their rentals by moving to Chicago. This suggests that Chicago has a relatively low quality of life. The matrix offers two quality of life estimators. The "exit" index represents the percentage of people who can leave a city and have higher predicted wages and a lower predicted rent. The greater is this number the higher is the city's quality of life. This ranking suggests the following order: 1. Los Angeles, 2. New York, 3. San Francisco, 4. San Diego, 5. Chicago, 6. Houston. The "entry" index represents the percentage of people who can move to a city and have higher predicted wages and a lower predicted rent. This ranking suggests the following order: 1. Los Angeles, 2. San Francisco, 3. New York, 4. San Diego, 5. Houston, 6. Chicago. Thus the two methods yield similar but not identical results.

Table 5 presents the city quality of life surplus matrix defined in equation (6). This table indicates that the average person in New York must sacrifice a monthly payment of $\$ 18$ to live in Los Angeles. The units are 1967 dollars. The largest entry in the matrix is $\$ 91$ (for movers from New York to San Diego). I am surprised by how small these numbers are. Either these 6 large cities are relatively "close", or people do not pay much money for relative amenities improvements.

\section{$\underline{\text { V. Conclusion }}$}

This paper presented a new method for ranking city quality of life. This method does not require data on city specific attributes and requires weaker assumptions than the hedonic approach. This method can be used to rank city quality of life even if no city specific attributes are known. Thus this method can be used to rank city quality of life in the past. 
Table 1

Summary Statistics

\begin{tabular}{||l|c|c|c||}
\hline Variable & observations & Mean & Std. Dev. \\
\hline & & & \\
\hline rent in nominal 1980 dollars & 1307 & 100.9 & 107.7 \\
\hline rent in real 1967 dollars & 1307 & 3.96 & 38.7 \\
\hline rooms & 1307 & 0.42 & 1.45 \\
\hline built before 1950 & 1307 & 0.16 & 0.49 \\
\hline built between 1950-1960 & 1307 & 0.22 & 0.37 \\
\hline built between 1960-1970 & 1307 & 8.36 & 0.41 \\
\hline wage in nominal 1980 dollars & 1307 & 3.00 & 4.34 \\
\hline wage in real 1967 dollars & 1307 & 15.5 & 1.56 \\
\hline school & 1307 & 14.1 & 3.08 \\
\hline experience & 1307 & 351.6 & 12.4 \\
\hline experience squared & 1307 & 498.9 \\
\hline Schooling units equal last completed grade plus two. Thus a high school graduate has schooling equal to 14. \\
\hline
\end{tabular}


Table 2

\section{City Log Wage Regressions}

\begin{tabular}{|c|c|c|c|c|c|c|}
\hline \multicolumn{7}{|c|}{ Dependent Variable: Real Log Wage in 1980} \\
\hline & Chicago & Houston & Los Angeles & New York & San Diego & $\begin{array}{r}\text { San } \\
\text { Francisco }\end{array}$ \\
\hline education & $\begin{array}{r}0.03 \\
(3.17) \\
\end{array}$ & $\begin{array}{l}0.026 \\
(2.10) \\
\end{array}$ & $\begin{array}{l}0.034 \\
(3.53) \\
\end{array}$ & $\begin{array}{r}0.056 \\
(8.42) \\
\end{array}$ & $\begin{array}{r}0.03 \\
(1.39) \\
\end{array}$ & $\begin{array}{l}0.016 \\
(1.28) \\
\end{array}$ \\
\hline experience & $\begin{array}{r}0.02 \\
(3.09)\end{array}$ & $\begin{array}{r}0.02 \\
(1.87)\end{array}$ & $\begin{array}{l}0.028 \\
(3.78)\end{array}$ & $\begin{array}{r}0.02 \\
(3.82)\end{array}$ & $\begin{array}{r}0.03 \\
(2.08)\end{array}$ & $\begin{array}{l}0.026 \\
(2.94)\end{array}$ \\
\hline $\begin{array}{l}\text { experience } \\
\text { squared }\end{array}$ & $\begin{array}{r}-0.0004 \\
(-2.14)\end{array}$ & $\begin{array}{r}-0.0005 \\
(-1.62)\end{array}$ & $\begin{array}{r}-0.0005 \\
(-2.71)\end{array}$ & $\begin{array}{r}-0.0003 \\
(-1.96)\end{array}$ & $\begin{array}{r}-0.0001 \\
(-0.13)\end{array}$ & $\begin{array}{r}-0.0004 \\
(-1.88)\end{array}$ \\
\hline constant & $\begin{array}{r}0.39 \\
(2.26)\end{array}$ & $\begin{array}{r}0.38 \\
(1.76)\end{array}$ & $\begin{array}{r}0.22 \\
(1.30)\end{array}$ & $\begin{array}{r}-0.11 \\
(-0.85)\end{array}$ & $\begin{array}{r}0.10 \\
(0.26)\end{array}$ & $\begin{array}{r}0.59 \\
(2.61)\end{array}$ \\
\hline observation & 224 & 127 & 282 & 454 & 71 & 149 \\
\hline R Squared & 0.09 & 0.05 & 0.09 & 0.15 & 0.35 & 0.09 \\
\hline \multicolumn{7}{|c|}{$\begin{array}{l}\text { Note: t-statistics are in parentheses. The dependent variable is the log of a man's nominal wage in } 1980 \text { divided by the } \\
\text { city food cpi index where the base year is } 1967 \text {. The independent variables include schooling, measured in years, } \\
\text { experience defined as age - schooling - } 6 \text {. For each city, I estimate this wage regression using least squares on data from } \\
\text { the } 1980 \text { Census of Population and Housing Public Use Microdata A Sample. }\end{array}$} \\
\hline
\end{tabular}


Table 3

City Log Rental Regressions

\begin{tabular}{|c|c|c|c|c|c|c|}
\hline \multicolumn{7}{|c|}{ Dependent Variable: Real Log Rent in 1980} \\
\hline & Chicago & Houston & Los Angeles & New York & San Diego & $\begin{array}{r}\text { San } \\
\text { Francisco }\end{array}$ \\
\hline $\begin{array}{l}\text { built pre- } \\
1950\end{array}$ & $\begin{array}{r}-0.41 \\
(-7.85)\end{array}$ & $\begin{array}{r}-0.50 \\
(-4.73)\end{array}$ & $\begin{array}{r}-0.40 \\
(-6.41)\end{array}$ & $\begin{array}{r}-0.38 \\
(-5.34)\end{array}$ & $\begin{array}{r}-0.10 \\
(-0.81)\end{array}$ & $\begin{array}{r}-0.21 \\
(-3.11)\end{array}$ \\
\hline built $1950-60$ & $\begin{array}{r}-0.17 \\
(-2.20)\end{array}$ & $\begin{array}{r}-0.42 \\
(-4.64)\end{array}$ & $\begin{array}{r}-0.25 \\
(-3.94)\end{array}$ & $\begin{array}{r}-0.27 \\
(-3.33)\end{array}$ & $\begin{array}{r}-0.13 \\
(-1.16)\end{array}$ & $\begin{array}{r}-0.15 \\
(-1.68)\end{array}$ \\
\hline built $1960-70$ & $\begin{array}{r}-0.06 \\
(-0.97)\end{array}$ & $\begin{array}{r}-0.06 \\
(-0.87)\end{array}$ & $\begin{array}{r}-0.17 \\
(-2.69)\end{array}$ & $\begin{array}{r}-0.11 \\
(-1.37)\end{array}$ & $\begin{array}{r}-0.07 \\
(-0.74)\end{array}$ & $\begin{array}{r}-0.06 \\
(-0.73)\end{array}$ \\
\hline rooms & $\begin{array}{r}0.06 \\
(4.11)\end{array}$ & $\begin{array}{r}0.09 \\
(4.87)\end{array}$ & $\begin{array}{r}0.12 \\
(8.79)\end{array}$ & $\begin{array}{r}0.04 \\
(2.64)\end{array}$ & $\begin{array}{r}0.07 \\
(2.82)\end{array}$ & $\begin{array}{r}0.11 \\
(6.22)\end{array}$ \\
\hline constant & $\begin{array}{r}4.47 \\
(61.3)\end{array}$ & $\begin{array}{r}4.21 \\
(46.7)\end{array}$ & $\begin{array}{r}4.38 \\
(62.6)\end{array}$ & $\begin{array}{r}4.66 \\
(55.2) \\
\end{array}$ & $\begin{array}{r}4.39 \\
(40.8)\end{array}$ & $\begin{array}{r}4.34 \\
(45.0)\end{array}$ \\
\hline observations & 220 & 125 & 278 & 449 & 71 & 143 \\
\hline$R$ squared & 0.28 & 0.34 & 0.29 & 0.12 & 0.11 & 0.30 \\
\hline \multicolumn{7}{|c|}{$\begin{array}{l}\text { Note: t-statistics are in parentheses. The dependent variable is the log an apartment's nominal rent in } 1980 \text { divided by the } \\
\text { city food cpi index where the base year is } 1967 \text {. The independent variables include dummy variables indicating whether } \\
\text { the apartment was built before } 1950 \text {, between } 1950 \text { and } 1960 \text {, between } 1960 \text { and } 1970 \text {. The omitted category is built } \\
\text { between } 1970 \text { and } 1980 \text {. The number of rooms in the apartment is also included in the regression. For each city, I } \\
\text { estimate this rental regression using least squares on data from the } 1980 \text { Census of Population and Housing Public Use } \\
\text { Microdata A Sample. }\end{array}$} \\
\hline
\end{tabular}




\section{Table 4}

\section{City Quality of Life Transition Matrix}

\begin{tabular}{|c|c|c|c|c|c|c|c|}
\hline \multicolumn{8}{|c|}{ Percent of people who can raise their wages and lower their rental by switching cities. } \\
\hline $\begin{array}{l}\text { move to } \\
\text { move } \\
\text { from }\end{array}$ & Chicago & Houston & $\begin{array}{r}\text { Los } \\
\text { Angeles }\end{array}$ & $\begin{array}{l}\text { New } \\
\text { York }\end{array}$ & $\begin{array}{r}\text { San } \\
\text { Diego }\end{array}$ & $\begin{array}{r}\text { San } \\
\text { Francisco }\end{array}$ & exit index \\
\hline Chicago & - & 0 & 0 & 2 & 12 & .4 & 1.7 \\
\hline Houston & 2 & - & 0 & 2 & 4 & 0 & 1.4 \\
\hline $\begin{array}{l}\text { Los } \\
\text { Angeles }\end{array}$ & 82 & 22 & - & 25 & 21 & 17 & 35.7 \\
\hline $\begin{array}{l}\text { New } \\
\text { York }\end{array}$ & 70 & 20 & 14 & - & 18 & 10 & 29.3 \\
\hline $\begin{array}{l}\text { San } \\
\text { Diego }\end{array}$ & 13 & 70 & 8 & 18 & - & 1 & 18.1 \\
\hline $\begin{array}{l}\text { San } \\
\text { Francisco }\end{array}$ & 54 & 1 & 6 & 17 & 22 & - & 20.1 \\
\hline $\begin{array}{l}\text { entry } \\
\text { index }\end{array}$ & 59.3 & 17.4 & 7.6 & 13.6 & 15.3 & 8.2 & \\
\hline \multicolumn{8}{|c|}{$\begin{array}{l}\text { Note: Element }(\mathrm{i}, \mathrm{j}) \text { of this matrix represents the percent of people living in city } i \text { that I predict can raise their } \\
\text { wages and lower their rentals by moving to city } \mathrm{j} \text {. For example, (San Diego, Chicago) equals } 13 \text {. This means } \\
\text { that } 13 \text { percent of the people living in San Diego can raise their predicted wages and lower their predicted } \\
\text { rentals by moving to Chicago. The entry index is the weighted average of the rows. The exit index is the } \\
\text { weighted average of the columns. See equation (5) in the text. }\end{array}$} \\
\hline
\end{tabular}




\section{Table 5}

\section{City Quality of Life Surplus Matrix}

\begin{tabular}{|c|c|c|c|c|c|c|}
\hline \multicolumn{7}{|c|}{ Predicted Increase in Monthly Income from switching cities } \\
\hline $\begin{array}{l}\text { move to } \\
\text { move from }\end{array}$ & Chicago & Houston & Los Angeles & New York & San Diego & $\begin{array}{r}\text { San Fran- } \\
\text { cisco }\end{array}$ \\
\hline Chicago & - & -55 & -60 & -45 & 0.95 & -15 \\
\hline Houston & 49 & - & -13 & -3 & 22 & 36 \\
\hline Los Angeles & 54 & 1 & - & 10 & 49 & 42 \\
\hline New York & 37 & -30 & -18 & - & 91 & 29 \\
\hline San Diego & 43 & -2 & -18 & -7 & - & -25 \\
\hline $\begin{array}{l}\text { San } \\
\text { Francisco }\end{array}$ & 18 & -37 & -39 & -24 & 7 & - \\
\hline \multicolumn{7}{|c|}{$\begin{array}{l}\text { Note: Element }(\mathrm{i}, \mathrm{j}) \text { of this matrix represents the predicted gain in monthly income from moving from city } \mathrm{i} \text { to city } \mathrm{j} \text {. For } \\
\text { example, (San Diego, Chicago) equals } 43 \text {. This means that on average a person who moves from San Diego to Chicago } \\
\text { will enjoy a } 43 \text { dollar increase in monthly income. Units are } 1967 \text { dollars. See equation (6) in the text. }\end{array}$} \\
\hline
\end{tabular}




\section{REFERENCES}

Abelson, Peter and A. Markandya. "The Interpretation of Capitalized Hedonic Prices in a Dynamic Environment." Journal of Environmental Economics and Management. (September 1985) 12(3), pp. 195-206.

Blomquist, Glenn and Mark Berger and John Hoehn. "New Estimates of Quality of Life in Urban Areas." American Economic Review (March 1988), pp. 89-107.

Gyourko, Joseph and Joseph Tracy. "The Structure of Local Public Finance and the Quality of Life." Journal of Political Economy. (August 1991), pp. 774-806.

Heckman, James and Jose Scheinkman. "The Importance of Bundling in a Gorman-Lancaster Model of Earnings." The Review of Economic Studies. (April 1987), pp. 243-256.

Liu, Ben-Chieh. Quality of Life Indicators in U.S. Metropolitan Areas; A Statistical Analysis. Prager 1976.

Moulton, Brent. "An Illustration of A Pitfall In Estimating the Effects Of Aggregate Variables On Micro Units." The Review of Economics and Statistics. (1990), pp. 334-338.

Phillips, Robyn. "Residential Capitalization Rates: Explaining Intermetropolitan Variation, 19741979." Journal of Urban Economics. (1988) 23 pp. 278-290.

Roback, Jennifer. "Wages Rents and Quality of Life." Journal of Political Economy. (December 1982), pp. 1257-1278.

Rosen, Sherwin. "Wage Based Indices of Urban Quality of Life." In Current Issues in Urban Economics. Edited by Peter Mieszkowski and Mahlon Straszheim. Baltimore: Johns Hopkins University Press 1979.

Rosen, Sherwin. "A Note on Aggregation of Skills and Labor Quality." Journal of Human Resources. (Summer 1983) 18(3), pp. 425-431.

Rosen, Sherwin. "Hedonic Prices and Implicit Markets: Product Differentiation in Pure Competition." Journal of Political Economy (February 1974) 82(1), pp. 34-55. 


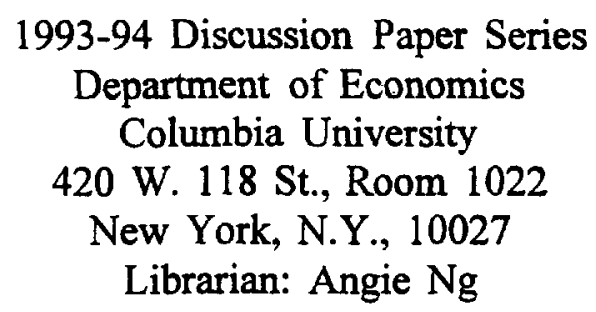

The following papers are published in the 1993-94 Columbia University Discussion Paper series which runs from November 1 to October 31. Domestic orders for discussion papers are available for purchase at $\$ 5.00$ (U.S.) each and $\$ 140.00$ (U.S.) for the series. Foreign orders cost $\$ 8.00$ (U.S.) for individual paper and $\$ 185.00$ for the series. To order discussion papers, please send your check or money order payable to Department of Economics, Columbia University to the above address. Please be sure to include the series number for the paper when you place an order.

671. Investment in U.S. Education and Training

Jacob Mincer ( Nov. 1993)

672. Freer Trade and the Wages of the Unskilled: Is Marx Striking Again?

Jagdish Bhagwati and Vivek Dehejia

673. Employer Size and Labor Turnover

Todd Idson

674. Less Crime May Be Worse

Brendan O'Flaherty

675. Team Production Effects on Earnings

Todd Idson

676. Language, Employment, and Earnings in the United States:

Spanish-English Differentials from 1970 to 1990

David Bloom and Gilles Grenier

677. The Impact of Performance Incentives on Providing Job Training to the Poor: The Job Training to the Poor: The Job Training Partnership

Act (JTPA)

Michael Cragg

678. The Demands to Reduce Domestic Diversity among Trading Nations Jagdish Bhagwati

679. Mass Layoffs and Unemployment

Andrew Caplin and John Leahy 
680. The Economics of Adjustment

Andrew Caplin and John Leahy

681. Miracle on Sixth Avenue: Information Externalities and Search Andrew Caplin and John Leahy

682. Arbitrage, Gains from Trade and Scoial Diversity: A Unified Perspective on Resource Allocation Graciela Chichilnisky

683. Who should abate carbon emissions? Graciela Chichilnisky, Geoffrey Heal

684. Believing in Multiple Equilibria Graciela Chichilnisky

685. Limited Arbitrage, Gains from Trade and Arrow's Theorem Graciela Chichilnisky

686. International Emission Permits: Equity and Efficiency Graciela Chichilnisky, Geoffrey Heal and David Starrett

687. Do Vehicle Emissions Testing Program Improve Air Quality? Matthew Kahn

688. Sources of Real Exchange Rate Fluctuations: How Important Are Nominal Shocks? Richard Clarida and Jordi Gali

689. Modeling Soviet Agriculture for Assessing Command Economy Policies Padma Desai and Balbir Sihag

690. The Changing Labor Market Position of Canadian Immigrants David Bloom, Gilles Grenier and Morley Gunderson

691. Herd Behavior, the " Penguin Effect ", and the Suppression of Informational Diffusion: An Analysis of Informational Externalities and Payoff Interdependency Jay Pil Choi 